\title{
過給式流動炉実証プラントにおける下水污泥の燃焼特性評価 \\ Evaluation of Combustion Characteristics of Sewage Sludge using a Demonstration Plant in Fluidized Bed Incinerator with Turbocharger
}

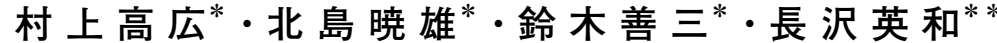 \\ 山本隆文 ${ }^{* *}$ ・小関 多賀美 ${ }^{* * *}$ ・廣瀬 均***・岡 本 誠一郎****
}

Takahiro MURAKAMI, Akio KITAJIMA, Yoshizo SUZUKI, Hidekazu NAGASAWA

Takafumi YAMAMOTO, Takami KOSEKI, Hitoshi HIROSE and Seiichiro OKAMOTO

(Received December 12, 2008)

\begin{abstract}
A new type of sewage sludge incinerator, which combines a pressurized fluidized bed combustor and a turbocharger driven by flue gas, was proposed. We constructed a demonstration plant (4.32 t/d scale) at a sewage works in Oshamanbe Cho in Hokkaido. The objectives of this study were combustion characteristics of de-watered sludge in this plant. Additionally, the characteristics between our new plant and a conventional one were compared using the experimental results. As the results, $\mathrm{CO} \mathrm{NO}_{\mathrm{x}}$, and $\mathrm{N}_{2} \mathrm{O}$ emissions were substantially reduced by the pressurization. $\mathrm{N}_{2} \mathrm{O}$ emission could be controlled by the freeboard temperature in spite of the high nitrogen content of the fuel and the pressurized conditions. In particular, $\mathrm{N}_{2} \mathrm{O}$ emission of the new plant was less half of that of the conventional plant. It is thought that $\mathrm{N}_{2} \mathrm{O}$ was decomposed at a local high temperature place in the freeboard. This phenomenon was verified qualitatively by investigating the chemical reaction rates. Therefore, our new fluidized bed incinerator with the turbocharger had a low environmental impact.
\end{abstract}

Key Words: Sewage Sludge, Fluidized Bed Combustor, Turbocharger, Pressurization, Nitrous Oxide

\section{1. 緒言}

前報 1)では、燃焼炉を加圧流動層とし、その後段に過給 機を設置して、排ガスにより駆動させることで燃焼空気を 生成させる過給式流動炉システムの概要を紹介した。さら に加圧流動層燃焼炉に着目して、研究室規模の加圧流動層 による下水污泥の基礎燃焼特性について報告した。本報で は、北海道長万部町の終末処理場内に建設した污泥燒却プ ラント実証設備（4.32 t/d）の運転結果について報告する。

\section{2. 実験装置および方法}

Fig. 1 に実証プラントの概略図を示す。本プラントは、 燃料フィーダ、加圧バブリング流動層燃焼炉、空気予熱器、 セラミックフィルタ、過給機抢よび排気筒からなる。燃焼 炉は内径 $700 \mathrm{~mm}$ 、高さ $9200 \mathrm{~mm}$ で、炉内温度は熱電対に

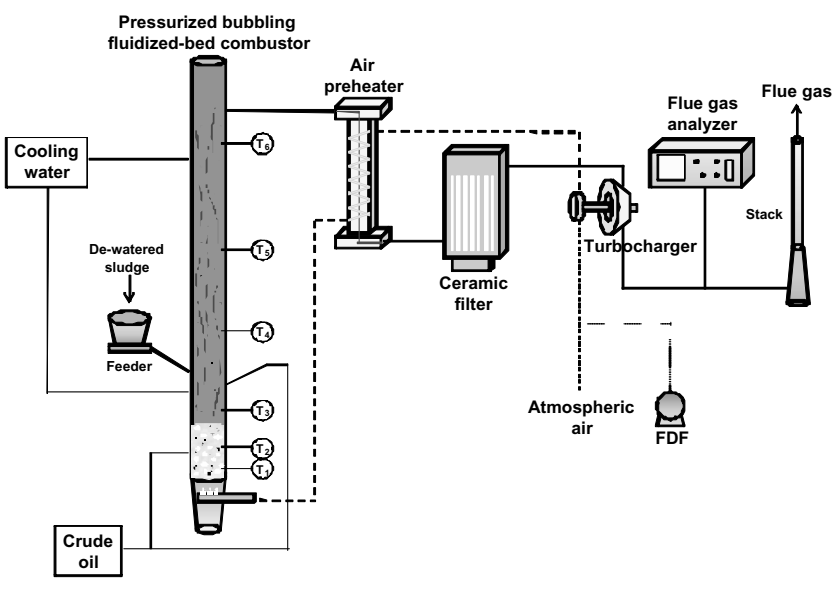

Fig. 1 Schematic diagram of a demonstration plant.

*独立行政法人 産業技術総合研究所エネルギー技術研究部門クリーンガスグループ（† 305-8569 茨城県つくば市小野川 16-1） Clean Gas Group, Energy Technology Research Institute, National Institute of Advanced Industrial Science and Technology(AIST) (16-1 Onogawa, Tsukuba, Ibaraki 305-8569 Japan)

**月島機械株式会社（ $\bar{T} 104-0051$ 東京都中央区佃 2丁目 17-15

Tsukishima Kikai Co., Ltd. (17-15 Tsukuda 2-chome, Chuo-ku, Tokyo 104-0051 Japan)

$* * *$ 三機工業株式会社（～242-0001 神奈川県大和市下鶴間 1742-7）

Sanki Engineering Co., Ltd. (1742-7 Shimotsuruma, Yamato, Kanagawa 242-0001 Japan)

****独立行政法人 土木研究所（テ 305-8516 茨城県つくば市南原 1-6）

Public Works Research Institute(PWRI) (1-6 Minamihara, Tsukuba, Ibaraki 305-8516 Japan) 
過給式流動炉実証プラントにおける下水污泥の燃焼特性評価（村上・北島・鈴木・長沢・山本・小関・廣瀬・岡本）

Table 1 De-watered sludge properties

\begin{tabular}{|c|c|c|}
\hline \multicolumn{2}{|l|}{ Moisture [wt\%] } & 87.0 \\
\hline \multicolumn{2}{|l|}{ Ignition loss [dry, wt\%] } & 85.0 \\
\hline \multirow{3}{*}{$\begin{array}{c}\text { Ultimate analysis } \\
\text { [dry, wt\%] }\end{array}$} & $\mathrm{C}$ & 43.7 \\
\cline { 2 - 3 } & $\mathrm{H}$ & 6.84 \\
\cline { 2 - 3 } & $\mathrm{N}$ & 7.50 \\
\cline { 2 - 3 } & $\mathrm{S}$ & 0.96 \\
\cline { 2 - 3 } & $\mathrm{O}$ & 26.1 \\
\hline \multicolumn{2}{|c|}{ Higher heating value [MJ/kg (d.b.)] } & 20.1 \\
\hline
\end{tabular}

より測定した（砂層内：300 および $600 \mathrm{mm、フリーボード：}$ $1300,3000,4600$ および $6800 \mathrm{~mm}$ の計 6 点、数值は分散板 からの高さ)。流動媒体は、平均粒子径が 400 および $700 \mu$ $\mathrm{m}$ の混合硅砂を使用した。運転中の層高は $950 \mathrm{~mm}$ である。 過給機は貨物自動車のディーゼルエンジンに搭載されてい る汎用品で、仕様を以下に示す。重量: $10.5 \mathrm{~kg}$, 出口空気量: $120-900 \mathrm{~m}_{\mathrm{N}}^{3} / \mathrm{h}$, 最大圧力比 : 3.0 , 最大運転温度 : $1023 \mathrm{~K}$ 。

燃料性状を Table 1 に示す。污泥中の水分は $87 \mathrm{wt} \%$ 、窒 素含有量は $7.5 \mathrm{wt} \%$ であり、石炭や木材のような他の固体 燃料よりもかなり高い。性状は実験毎に分析した。

本設備の操作手順として、フリーボードに相当する分散 板から $1750 \mathrm{~mm}$ の位置より、A 重油を流動層炉内へ供給す ることで昇温させた。炉内温度が $873 \mathrm{~K}$ を超えると、供給 点は砂層に該当する $500 \mathrm{~mm}$ へと変更させた。流動空気は 過給機によって供給した。起動から自立運転開始までは、 流動ブロワから圧縮空気も供給することにより過給機を駆 動させ、過給機の入口温度が $623 \mathrm{~K}$ を超えると、流動ブロ ワを停止させて自立運転に切り替えた。すなわち、燃焼炉 からの排ガスのみを駆動源とした。炉内温度が $1073 \mathrm{~K}$ を 超えると、分散板から $2100 \mathrm{~mm}$ の位置より脱水污泥を燃料 フィーダによって供給した。実験中、空気予熱器の温度が $1123 \mathrm{~K}$ を超えると、空気予熱器の耐熱温度の影響から燃焼 炉内へ冷却水を供給した。燃焼後の排ガスは、空気予熱器、 セラミックフィルタおよび過給機を経て、大気中へ放出し た。空気予熱器により、燃焼後の高温排ガスと過給機から 生成した然焼用空気との間で熱交換を行い、その後段のセ ラミックフィルタでは、主に脱塵を行った ${ }^{2)}$ 。

実験条件は、脱水污泥供給量は $180 \sim 190 \mathrm{~kg} / \mathrm{h}$ とし、炉

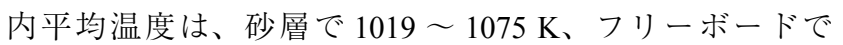
$1138 \sim 1205 \mathrm{~K}$ 、圧力は絶対圧で約 $0.2 \mathrm{MPa}$ とした。空気比 は排ガス中の $\mathrm{O}_{2}$ 濃度べースで約 1.6 とし、炉内のガス速度 は、 $\mathrm{U}_{\mathrm{o}} / \mathrm{U}_{\mathrm{mf}}$ で約 6.0 とした。排ガス分析は、 $\mathrm{O}_{2}, \mathrm{CO}, \mathrm{CO}_{2}$ お よび $\mathrm{NO}_{\mathrm{x}}$ は連続分析計 (IR400 横河電機(株)、VA-3000 (株)堀 場製作所）により分析し、 $\mathrm{N}_{2} \mathrm{O}$ はガスクロマトグラフ（CP4000, Varian Inc.）により分析した。

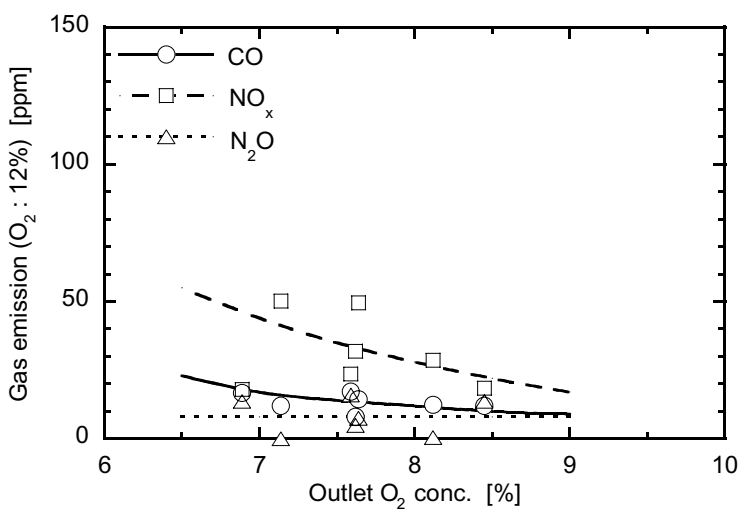

Fig. 2 Relationship between $\mathrm{CO}, \mathrm{NO}_{x}$, and $\mathrm{N}_{2} \mathrm{O}$ emissions and $\mathrm{O}_{2}$ concentration in the flue gas.

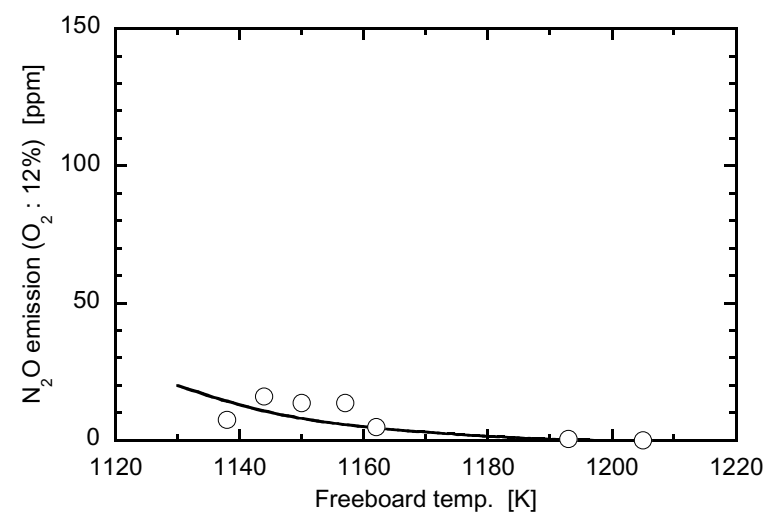

Fig. 3 Dependency of $\mathrm{N}_{2} \mathrm{O}$ emission on freeboard temperature.

\section{3. 実験結果および考察}

3.1 排ガス特性

Fig. 2 に、排ガス中の $\mathrm{O}_{2}$ 濃度と $\mathrm{CO}, \mathrm{NO}_{\mathrm{x}}$ および $\mathrm{N}_{2} \mathrm{O}$ 濃 度の関係を示す。まず $\mathrm{CO}$ において、 $\mathrm{O}_{2}$ 濃度が低下するに 連れて、CO 濃度は若干高くなっているが、全ての条件で 低濃度を維持できた。これは加圧により炉内の $\mathrm{O}_{2}$ 分圧が 増加したことで、燃焼速度が促進されたためと考える。つ ぎに $\mathrm{NO}_{\mathrm{x}}$ に関しては、本来 $\mathrm{O}_{2}$ 濃度が増加するに連れて増 加する傾向にあるが3),4)、本結果は逆の結果が得られた。さ らに、石炭然焼場での $\mathrm{NO}_{\mathrm{x}}$ 放出濃度よりも低濃度となった。 污泥中の水分はとても高いため、Oラジカルや $\mathrm{OH}$ ラジカ ル濃度に影響を与え、NO 生成反応を抑制する効果がある ${ }^{5)}$ さらに、加圧条件により水蒸気分圧が高くなるので、 $\mathrm{NO}_{x}$ 抑制効果も大きくなると推測できる。 $\mathrm{N}_{2} \mathrm{O}$ に関しては、 $\mathrm{O}_{2}$ 濃度が変化してもほとんど変化しなかった。これまでの研 究では、常圧流動層燃焼炬における排ガス中の $\mathrm{N}_{2} \mathrm{O}$ 濃度は

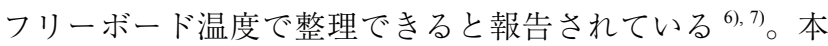
研究のような高 $\mathrm{N}$ 含有量燃料および加圧条件においても、 Fig. 3 に示すように、 $\mathrm{N}_{2} \mathrm{O}$ 濃度はフリーボード温度で整理 


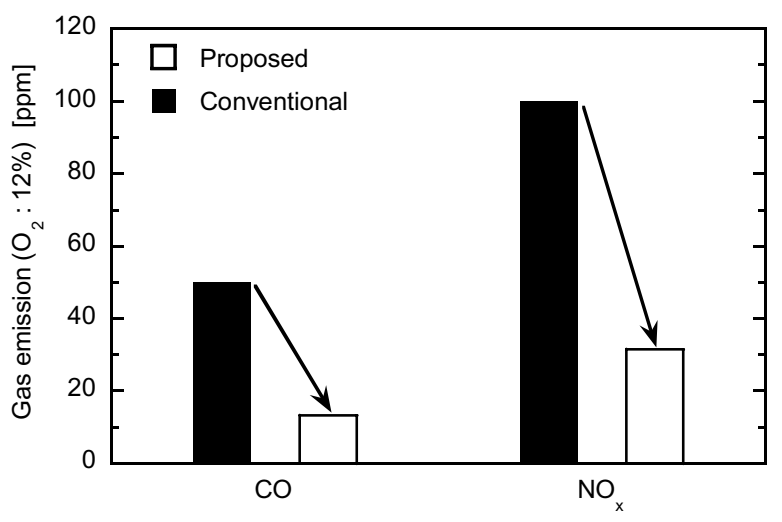

Fig. 4 Comparison of $\mathrm{CO}$ and $\mathrm{NO}_{\mathrm{x}}$ emissions.

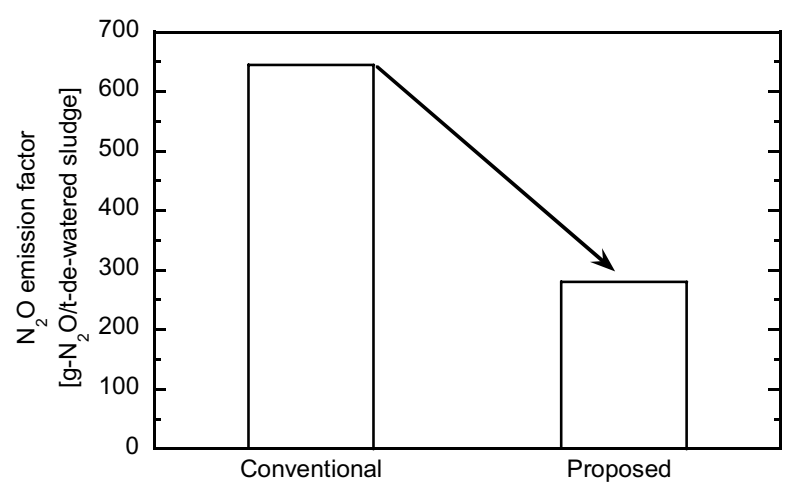

Fig. 5 Comparison of $\mathrm{N}_{2} \mathrm{O}$ emission factors.

できることが分かったり。

\section{2 過給式流動炉と従来型燃焼炉との燃焼特性の比較}

Fig. 4 に、過給式流動炉と従来型（常圧）燃焼炉におけ る排ガス中の $\mathrm{CO}$ および $\mathrm{NO}_{\mathrm{x}}$ 濃度の比較を示す 2 ) 8)。両濃 度とも前述したような加圧の効果により、従来設備よりも 半分以下の濃度となった。つづいて、 $\mathrm{N}_{2} \mathrm{O}$ 排出係数を比較 した結果を Fig. 5 に示す9 。 $\mathrm{N}_{2} \mathrm{O}$ 排出倸数とは、1 1 トンの 脱水污泥から排出される $\mathrm{N}_{2} \mathrm{O}$ 量で定義される。フリーボー ド温度 $1123 \mathrm{~K}$ で比較した。結果として、従来型よりも半分 以下に低減できることが分かった。

$\mathrm{N}_{2} \mathrm{O}$ 排出量を低減できる要因として、燃焼炉内温度分布 （Fig. 6）より考察した。本図中の従来型のデー夕は、本実 証プラントと同規模の運転データを使用した。過給式流動 炬においては、分散板より $3000 \mathrm{~mm}$ 付近のところで局所的 な高温域を形成している。これは、加圧により燃焼速度が 促進されたことで、砂層内で熱分解したガスが、この付近 で然焼していると考える。一方、従来型に扔いては、過給 式流動炉よりもフリーボード内の温度上昇が緩慢であるこ とから、熱分解ガスはフリーボード全体で燃焼していると 考える。したがって、過給式流動炉では、局所的な高温域

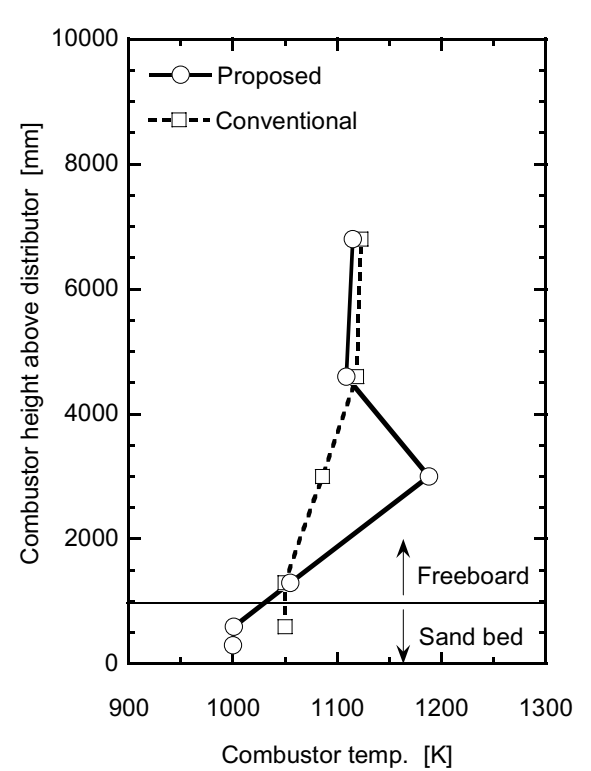

Fig. 6 Comparison of temperature distribution in the combustor.

で $\mathrm{N}_{2} \mathrm{O}$ が分解され易くなるので、排出量を低減できるとい える。この圧力により温度分布に顕著な差異が生じる現象 をシミュレーション（CHEMKIN Ver. 3.7）により定性的に 評価した。本シミュレーションでは燃焼反応式を組み込み、 それらの反応式は GRI-Mech (HP: http://www.me.berkeley. edu/gri_mech/) より引用した。計算条件として、計算開始 点を砂層最上部とし、砂層内で脱水污泥は熱分解、A 重油 は燃焼がそれぞれ完結する、またガスの流れはプラグフ ローと仮定した。燃焼炉の規模は実証プラントを模擬し、 熱損失は 0 とした。本条件に执いて、燃焼炉内圧力が $0.1,0.2$ 㧍よび $0.3 \mathrm{MPa} に$ に打りる温度分布、さらにガス濃度をそれ ぞれ比較した。Fig. 7 に、燃焼炉内温度分布の圧力依存性 について示すが、圧力が高くなるほど温度上昇開始点が速 くなることが分かる。これは、Fig. 8 に示す各ガス濃度分 布（ガス中の $\mathrm{N}_{2}$ および $\mathrm{H}_{2} \mathrm{O}$ 濃度が他の組成よりも顕著に 高いため、横軸はモル比 0-0.1 の範囲に拡大した）からも 明らかなように、圧力が高いほど然焼速度が速くなること から、温度上昇開始も速くなる。今後、熱損失などを考慮 して、より定量的に評価していく。

以上より、過給式流動炉では、加圧の効果により従来型 流動炉よりも低環境負荷を達成できる。

\section{4. 結論}

過給式流動炉実証プラントにより、下水污泥の燃焼特性 を明らかにした。得られた結果を以下に示す。

1）排ガス中の $\mathrm{CO}$ 抢よび $\mathrm{NO}_{\mathrm{x}}$ 濃度は、従来型燃焼炉より も半分以下に低減できた。これは、炉内の酸素分圧が高 くなることで $\mathrm{CO}$ の燃焼速度が促進されること、水蒸気 分圧も高くなることで O および OH ラジカルにより NO 


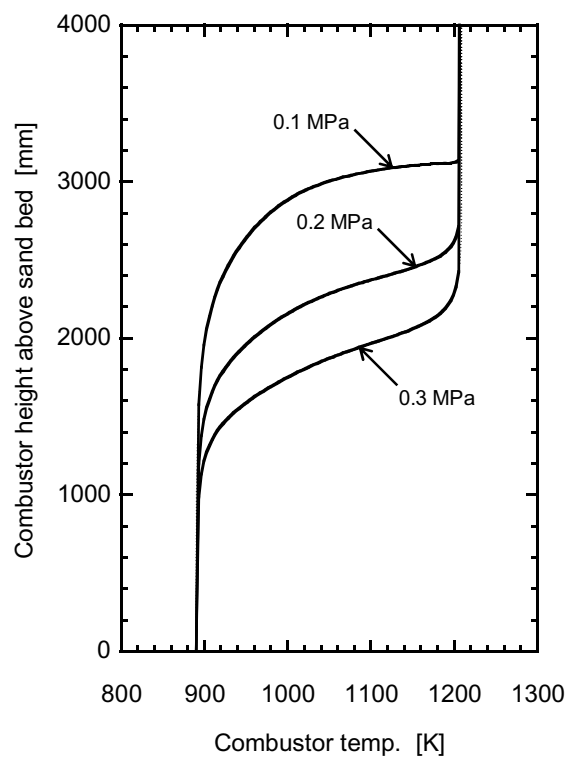

Fig. 7 Effect of pressure of temperature distribution in the freeboard by using simulation package.

生成反応を抑制することによる。

2) $\mathrm{N}_{2} \mathrm{O}$ 排出係数は、従来型燃焼炉よりも半分以下に低減で きた。これはフリーボード内に形成する局所的な高温域 で $\mathrm{N}_{2} \mathrm{O}$ が分解され易くなることによる。

3) 燃焼炉内の温度分布より、過給式流動炉では燃焼速度が 促進されることにより、フリーボードの下部で局所的な 高温域を形成するが、従来型燃焼炉では熱分解ガスがフ リーボード全体で然焼するため、過給式流動炉よりも緩 慢な温度上昇となった。本現象は、燃焼反応式を組み込 んだシミュレーションにより、定性的に明らかにでき た。

4) 過給式流動炉は低環境負荷の運転を達成できることが 分かった。

\section{謝 辞}

本研究は、「都市バイオマス収集システムを活用するため のエネルギー転換要素技術開発」の一環として、独立行政 法人 新エネルギー・産業技術総合開発機構（NEDO）か ら委託を受けて実施したものである。ここに記して、謝意 を表する。

\section{引用文献}

1）村上高広、鈴木善三、長沢英和、山本隆文、小関多賀美、廣瀬均、 落修一: 高温学会誌、34 (2008) 166-170.

2) 平成 17 年度〜 19 年度 NEDO 成果報告書: “「都市バイオマ ス収集システムを活用するためのエネルギー転換要素技術開 発」”(2008)

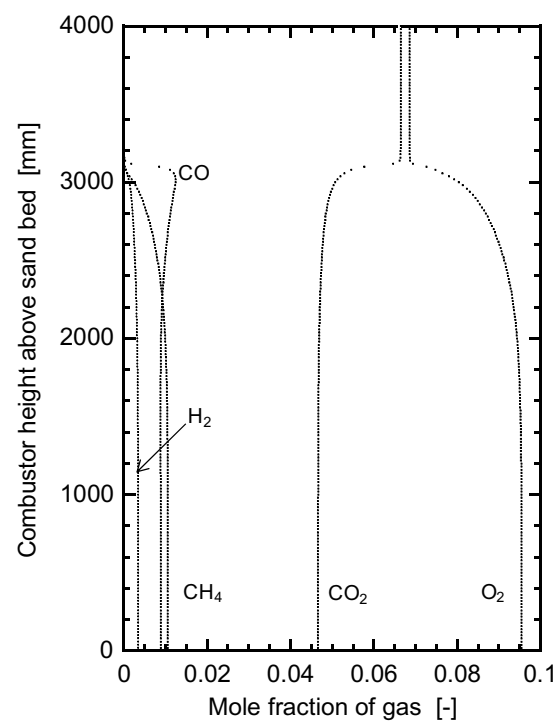

(a) $0.1 \mathrm{MPa}$

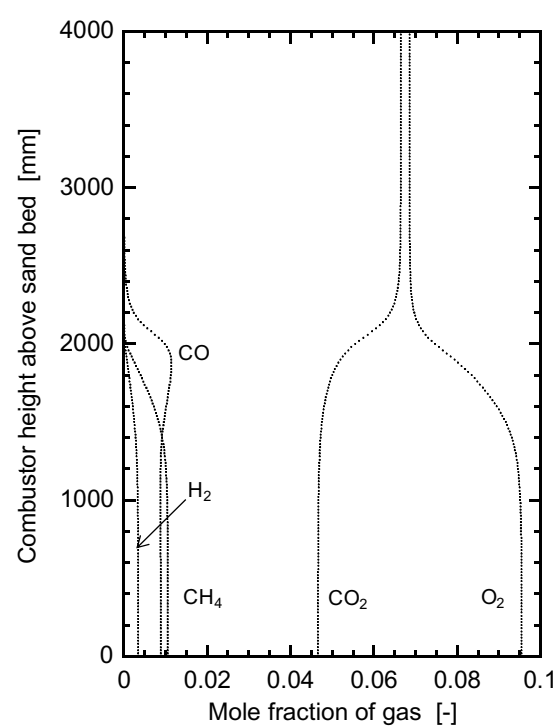

(b) $0.3 \mathrm{MPa}$

Fig. 8 Effect of pressure of flue gas concentration in the freeboard by using simulation package.

3) J. R. Pels, M. A. Wojtowicz, F. Kapteijn and J. A. Moulijn : Energy \& Fuels 9 (1995) 743-752.

4) B. Leckner : Prog. Energy Combust. Sci. 24 (1998) 31-61.

5) T. Ogada and J. Werther : Fuel 75 (1996) 617-626.

6) M. Shoji, T. Yamamoto, S. Tanno, H. Aoki and T. Miura : Energy 30 (2005) 337-345.

7) M. Sanger, J. Werther and T. Ogada : Fuel 80 (2002) 167-177.

8) 本多裕姫 : 地球環境、2 (2001) 98-102.

9) 清水俊昭：地球温暖化とインベントリ、下水道新技術推進機 構 -下水道機構だより (2007). 